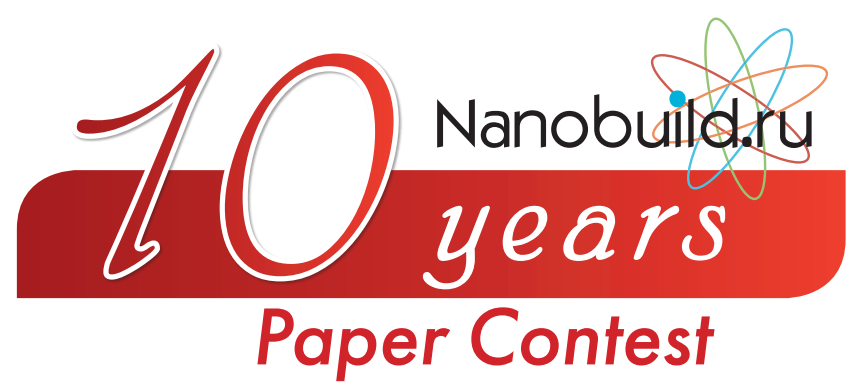

UDC 628.316.12, 622.793.2, 622.793.5, 69.001.5

Author: MALKIN Polad, Ph.D., Senior Researcher, Ben-Gurion University in the Negev, Israel;

P.O.B. 653 Beer-Sheva, 8410501, Israel, polad.malkin@gmail.com

\title{
WASTEWATER TREATMENT SYSTEM BASED ON NANOMODIFIED NATURAL SORBENTS
}

\section{Extended Abstract:}

Protection of water resources from contamination is considered as one of the global problem of the present day. Wastewater of almost all economic entities contains oil products, heavy metal compounds and other pollutants. Many effective wastewater treatment systems can provide purification index up to $99.9 \%$, but operation of such systems entails significant costs, therefore many economic entities neglect environmental protection standards despite heavy penalties.

The main task of modern technological systems is the development of environmentally safe technologies with the most closed cycle and the minimum amount of waste. The current situation in this field of research has necessitated the improvement of sorption technologies and selective processes for treatment of contaminated solutions and process fluids for the integrated solution of resource-saving and environmental problems. The target studies of wide range of sorption materials applied in wastewater treatment resulted in further development for processes of adsorption of oil products and heavy metal ions on natural sorbents and their analogs.

That is why design of cost-effective wastewater treatment systems that would ensure high purity is a challenge for all countries.

This paper suggests a multi-stage treatment system based on nanoactivated natural sorbents employed in a closed-loop water cycle. The advantage of using such treatment system as compared to the existing ones is demonstrated on the example of economic entities operating in the machine building industry in Russia, the USA and Israel.

Key words: natural sorbents, wastewater, ecology, water treatment, water treatment method, nanoactivation, closed-loop water cycle, activation, zeolite, diatomite, modification, nanotechnology. 
MACHINE-READABLE INFORMATION ON CC-LICENSES (HTML-CODE) IN METADATA OF THE PAPER

$<$ a rel="license" href="http://creativecommons.org/licenses/by/4.0/" $><$ img alt="Creative Commons License" style="borderwidth:0" src="https://i.creativecommons.org/l/by/4.0/88x31.png" / $></ \mathrm{a}><$ br $/><$ span xmlns:dct="http://purl.org/ $\mathrm{dc} /$ terms/" href="http://purl.org/dc/dcmitype/Text" property="dct:title" rel="dct:type" $>$ Wastewater treatment system based on nanomodified natural sorbents. $<$ span $>$ by $<$ a xmlns:cc="http://creativecommons.org/ns\#" href="Nanotehnologii $\mathrm{v}$ stroitel'stve $=$ Nanotechnologies in Construction. 2018, Vol. 10, no. 5, pp. 56-72. DOI: dx.doi.org/10.15828/20758545-2018-10-5-56-72." property="cc:attributionName" rel="cc:attributionURL" $>$ Malkin P. $</$ a $>$ is licensed under a $<$ a rel="license" href="http://creativecommons.org/licenses/by/4.0/">Creative Commons Attribution 4.0 International License $</ \mathrm{a}>$. $<$ br $/>$ Based on a work at $<$ a xmlns:dct="http://purl.org/dc/terms/" href="http://nanobuild.ru/en_EN/ nanobuild-5-2018/" rel="dct:source">http://nanobuild.ru/en_EN/nanobuild-5-2018/</a $>$. $<$ br $/>$ Permissions beyond the scope of this license may be available at $<$ a xmlns:cc="http://creativecommons.org/ns\#" href="polad.malkin@gmail.com" rel="cc:morePermissions" $>$ polad.malkin@gmail.com $</ a>$.

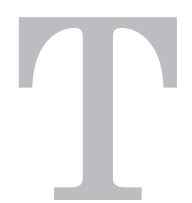

he issue related to the construction of a water treatment system is solved differently at different economic entities, because the technology of water treatment depends not only on the requirements for the quality of treated water, but also on the technological and economic feasibility of water treatment. Such methods as water treatment based on biological sludge, centrifugation, sorption, flotation, ultraviolet water treatment or ozonization, micro- and nanofiltration are successfully used for wastewater treatment. The most popular and effective methods of water and wastewater treatment are as follows: physicochemical treatment methods, biological methods, both aerobic and anaerobic, wastewater treatment based on membranes, thermal methods of water treatment, wastewater treatment based on ozone, absorption methods of treatment based on activated carbon, ion-exchange methods for the selective extraction of contaminants. Each of the methods above has its advantages and disadvantages. Selection of one or another method depends on a number of factors, such as the scale of contamination, its specificity and economic feasibility. The existing environmental protection standards require economic entities to implement new treatment facilities or modernize the existing ones [1-8].

In Russia the most popular methods of wastewater treatment are chemical and physicochemical methods. Chemical treatment is carried out with the use of a variety of chemical reagents that react with contaminants. As a result of their action insoluble deposits form. Physicochemical treatment of water combines several methods: coagulation - adding of coagulants to effluents during reaction that produces deposits in the form 
of flakes, which can simply be removed, flotation - passing of air bubbles through effluents. When moving up they take oils, surfactants and other contaminants with them. As a result, foam is formed on the surface of effluents, and sorption - the use of materials that can absorb contaminants. First, mechanical treatment is carried out.

Israel was recognized as the best country in terms of industrial wastewater treatment in 2010 and subsequent years. Today Israel remains one of the world leaders in this area. The main methods are as follows: chemical, mechanical, physicochemical, and biological. In addition to the traditional methods of water and wastewater treatment, new and more environmentally friendly and economically viable methods have been developed in Israel: membrane, electrochemical, magnetic treatment, ozonation, treatment with selective sorbents. Each of these methods allows removal various contaminants effectively with minimal harmful effect on the environment.

In the United States the most popular industrial method of wastewater treatment is the membrane treatment method. Growing interest to the technology of ultrafiltration among US specialists is caused by an increasing scale of its application. The method of membrane filtration is based on the following: when wastewater is passing through the membrane, it gives preference to some substances and retains impurities that are foreign for it. The main advantage of this method is almost complete treatment of liquid from foreign impurities and compounds. Thorough filtration prevents pollutants ingress to water.

An analysis of data on industrial wastewater treatment was conducted at economic entities of such countries as Russia, the United States and Israel. The data collected at five economic entities of the machine building industry in each country are presented in Table 1 , where $\mathrm{C}_{\mathrm{in}}$ - input impurity concentration, $\mathrm{C}_{\text {out }}$ - output impurity concentration, $\alpha$ - extraction degree.

The data in Table 1 are organized according to the average value of concentrations at the selected economic entities in the industry most polluted with heavy metals. The above results indicate that the methods used for treatment in Russia are inferior to the level of wastewater treatment at economic entities in the United States and Israel. All the methods used are quite expensive, especially in the USA and Israel. Searching for and development of new economically viable and highly effective water treatment methods is of top-priority importance for these countries. 
Concentrations of heavy metals in wastewater before and after treatment at economic entities of the machine building industry by country

\begin{tabular}{|c|c|c|c|c|c|c|c|c|c|}
\hline \multirow{3}{*}{$\begin{array}{l}\text { Extracted } \\
\text { substance }\end{array}$} & \multicolumn{3}{|c|}{ Russia } & \multicolumn{3}{|c|}{ USA } & \multicolumn{3}{|c|}{ Israel } \\
\hline & $\begin{array}{c}\mathrm{C}_{\mathrm{in}}, \\
\mathrm{mg} / \mathrm{l}\end{array}$ & $\begin{array}{c}\mathrm{C}_{\text {out }}, \\
\mathrm{mg} / \mathrm{l}\end{array}$ & $\alpha,(\%)$ & $\begin{array}{c}\mathrm{C}_{\mathrm{in}}, \\
\mathrm{mg} / \mathbf{l}\end{array}$ & $\begin{array}{l}\mathrm{C}_{\text {out }}, \\
\mathrm{mg} / \mathrm{l}\end{array}$ & $\alpha,(\%)$ & $\begin{array}{c}\mathrm{C}_{\mathrm{in}}, \\
\mathrm{mg} / \mathrm{l}\end{array}$ & $\begin{array}{l}\mathrm{C}_{\text {out }}, \\
\mathrm{mg} / \mathrm{l}\end{array}$ & $\alpha,(\%)$ \\
\hline & \multicolumn{9}{|c|}{$\mathrm{pH}=3-11$} \\
\hline $\mathrm{Fe}$ & 150.4 & 0.3 & 99.8 & 75.9 & 0.1 & 99.9 & 75.0 & 0.1 & 99.9 \\
\hline $\mathrm{Cu}$ & 10.3 & 0.4 & 96.1 & 9.7 & 0.35 & 96.4 & 13.6 & 0.3 & 97.8 \\
\hline $\mathrm{Zn}$ & 22.8 & 0.8 & 96.5 & 20.6 & 0.5 & 97.6 & 21.4 & 0.6 & 97.2 \\
\hline $\mathrm{Cr}_{\text {total }}$ & 95.3 & 0.3 & 99.7 & 89.5 & 0.2 & 99.8 & 90.7 & 0.2 & 99.8 \\
\hline $\mathrm{Ni}$ & 1.06 & 0.07 & 93.4 & 1.09 & 0.06 & 94.5 & 1.15 & 0.07 & 93.9 \\
\hline $\mathrm{Pb}$ & 2.6 & 0.1 & 96.1 & 2.9 & 0.08 & 97.2 & 2.2 & 0.04 & 98.2 \\
\hline $\mathrm{Cr}^{6+}$ & 3.5 & 0.1 & 97.1 & 2.5 & 0.05 & 98.0 & 2.5 & 0.05 & 98.0 \\
\hline Other & 6 & 0.2 & 96.6 & 4.5 & 0.02 & 99.6 & 4.7 & 0.01 & 99.8 \\
\hline
\end{tabular}

The use of nanomaterials with unique physicochemical and surface properties provides new opportunities in wastewater treatment. Implementation of nanotechnologies in wastewater treatment is a promising area for the improvement of the quality of treatment. So, paper [9] proposes to use sorption treatment with the help of nanomodified natural sorbents a nanoactivated complex of zeolite and diatomite - for the treatment of wastewater containing a wide range of pollutants. Natural zeolite and diatomite are distinguished by an increased ion-exchange capacity, the ability to exchange cations, low price and high popularity.

The main component of the selected natural sorbents is silicon oxide. Its content in diatomite reaches $80 \%$, in zeolite - about $70 \%$. These minerals also contain oxides of aluminum, iron, titanium, calcium, magnesium, sodium, potassium, and other oxides.

According to the method proposed in paper [9], the capacity of the sorbent to absorb large concentrations of heavy metals as compared to the 
concentrations at the selected economic entities specified in Table 1 was tested. The results of the tests are given in Table 2.

The degree of extraction was calculated according to the following equation:

$$
\alpha=\left(\mathrm{C}_{\text {in }}-\mathrm{C}_{\text {out }}\right) \cdot 100 / \mathrm{C}_{\text {in }} \text {, }
$$

where $\mathrm{C}_{\text {in }}$ is - input impurity concentration, $\mathrm{C}_{\text {out }}$ - output impurity concentration.

Table 2

Results of sorption of heavy metals by nanoactivated complex of natural sorbents

\begin{tabular}{|l|c|c|c|}
\hline \multirow{2}{*}{$\begin{array}{l}\text { Extracted } \\
\text { substance }\end{array}$} & \multicolumn{2}{|c|}{$\mathbf{p H}=\mathbf{3}-\mathbf{1 1}$} & \multirow{2}{*}{$\alpha,(\%)$} \\
\cline { 2 - 3 } & $\mathbf{C}_{\text {in }}, \mathbf{m g} / \mathbf{l}$ & $\mathbf{C}_{\text {out }}, \mathbf{m g} / \mathbf{l}$ & \\
\hline $\mathrm{Fe}$ & 200 & 0.1 & 99.9 \\
\hline $\mathrm{Cu}$ & 15 & 0.15 & 99 \\
\hline $\mathrm{Zn}$ & 27 & 0.15 & 99.4 \\
\hline $\mathrm{Cr}_{\text {total }}$ & 105 & 0.1 & 99.9 \\
\hline $\mathrm{Ni}$ & 5 & 0.01 & 99.8 \\
\hline $\mathrm{Pb}$ & 5 & 0.01 & 99.8 \\
\hline $\mathrm{Cr}^{6+}$ & 5 & 0.01 & 99.8 \\
\hline Other & 10 & 0.01 & 99.9 \\
\hline
\end{tabular}

According to the data presented in Table 2, the results of testing of the adsorption capacity of a nanomodified sorbent with respect to extracted substances showed that this sorbent can be successfully used for wastewater treatment from ions of heavy metals. So, the method of industrial wastewater treatment from heavy metals presented in paper [9] is the most effective.

It is proposed to introduce water cycles based on multi-stage treatment systems presented in paper [10] with the use of nanoactivated complexes of natural sorbents, as well as to reuse treated water in circulating cooling 


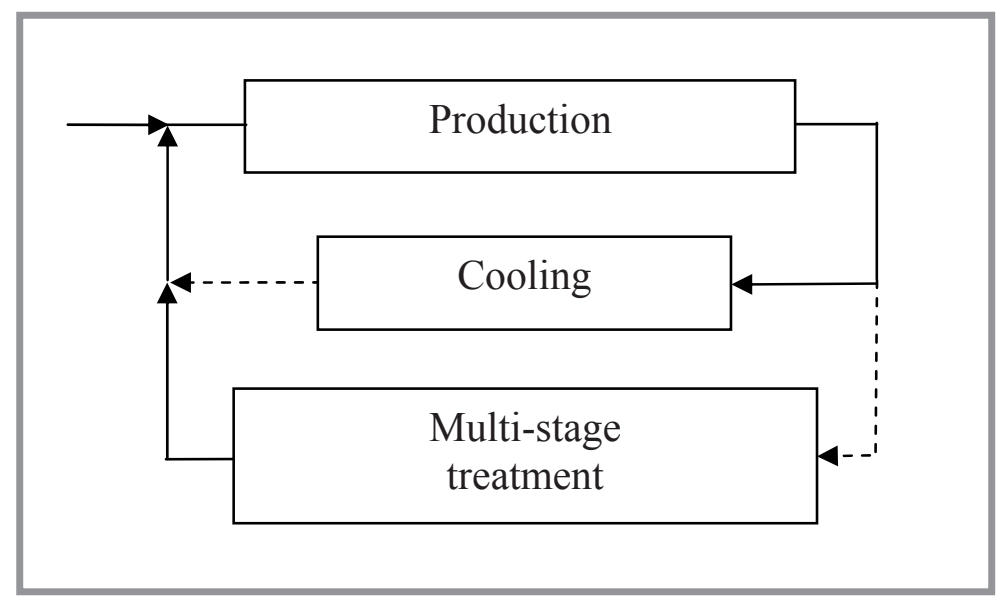

Fig. 1. Scheme of a closed-loop water cycle

water systems, etc. This system, which scheme is shown in Fig. 1, is the most cost-effective method of wastewater treatment for economic entities.

As distinct from a once-through water-supply system, which is usually used in case of low water consumption and closely located water sources, a full circulating water system presupposes water reuse for the purposes of production. Technologies that allow reusing treated wastewater or regenerating process solutions are of great importance. Most modern economic entities are active consumers of water resources. For the purposes of economic and environmental expediency it is advisable to give preference to a progressive method of recirculating water supply implying the repeated use of this resource. Reuse of wastewater after its treatment for the purposes of the same process operations or for other production needs is an effective way to reduce the number of industrial effluents discharged into reservoirs, as well as reduce costs of economic entities.

The main advantages of multi-stage systems in a close-loop water cycle for industrial effluents treatment based on nanomodified natural sorbents are as follows: a possibility to remove various compounds of heavy metals simultaneously on the first stage, heavy metal compounds are clathrated in the form of crystalline non-leachable products, dispersed suspensions and emulsified pollutants are removed effectively with dissolved heavy metals, the process is not sensitive to the influence of other salts that may be present in effluents in large concentrations [11-20].

The results of new treatment system testing proved more usefulness with respect to those ones used at economic entities in Russia, the United 
States and Israel. The degree of extraction is $99.9 \%$ combined with a high economic efficiency. Moreover, heavy metals are not released if the proposed sorbent is used, and the process of heavy metals absorption is actively continuing.

The analysis of the current state of wastewater treatment from heavy metals at the selected economic entities leads to a conclusion about the prospects of using the developed system based on nanomodified natural sorbents, as well as allows recommending them for practical use for wastewater treatment at economic entities of Russia, the United States and Israel.

\section{References:}

1. Javadian H., Ghorbani F., Tayebi H., Asl S.H. Study of the adsorption of Cd (II) from aqueous solution using zeolite-based geopolymer, synthesized from coal fly ash; kinetic, isotherm and thermodynamic studies. Arabian Journal of Chemistry. 2015, Vol. 8, Is. 6, P. 837-849.

2. Blanchard G., Maunaye M., Martin G. Removal of Heavy from Waters by Means of Natural Zeolites. Water Research. 1984, Vol. 18, Is. 12, P. 1501-1507.

3. Benkli Y.E., Can M.F., Turan M., Celik M.S. Modification of organo-zeolite surface for the removal of reactive azo dyes in fixed-bed reactors. Water Research. 2005, Vol. 39, Is. 2-3, P. 487-493.

4. Baker H.M., Massadeh A.M., Younes H.A. Natural Jordanian zeolite: Removal of heavy metal ions from water samples using column and batch methods. Environmental Monitoring and Assessment. 2009, Vol. 157, Is. 1-4, P. 319-330.

5. Gao Z., Bandosz T., Zhao Z., Han M. Investigation of factors affecting adsorption of transition metals on oxidized carbon nanotubes. Journal of Hazardous Materials. 2009, Vol. 167, Is. 1-3, P. 357-365.

6. Wan Ngah W.S., Hanafiah M.A. Removal of heavy metal ions from wastewater by chemically modified plant wastes as adsorbents: A Review. Bioresource Technology. 2008, Vol. 99, Is. 10, P. 3935-3948.

7. Cincotti A., Mameli A., Locci A.M., Orru R., Cao G. Heavy metals uptake by Sardinian natural zeolites: Experiment and modeling. Industrial \& Engineering Chemistry Research. 2006, Vol. 45, Is. 3, P. 1074-1084.

8. Margeta K., Logar N.Z., Šljeg M., FarkašA. Natural zeolites in water treatment - How effective is their use. INTECH, Open publication, 2013. http://dx.doi.org/10.5772/50738.

9. Malkin P. Wastewater treatment from heavy metal ions using nanoactivated complexes of natural zeolite and diatomite. Nanotehnologii v stroitel'stve $=$ Nanotechnologies in Construction. 2018, Vol. 10, no. 2, pp. 21-41. DOI: dx.doi. org/10.15828/2075-85452018-10-2-21-41. 
10. Malkin P. Method, system and device for cleaning and regeneration water. US Patent App. 62/592,411; 2017.

11. Malkin P. Method of Wastewater Treatment from Heavy Metal Ions Using Nanoactivated Complexes of Natural Zeolite and Diatomite. Young Scientist USA, Vol. 10, 2017, pp. 17-21.

12. Lukaszczyk J., Lekawska E., Lunkwitz K., Petzold G. Sorbents for Removal Surfactants from Aqueous Solutions. Surface Modification of Natural Solids to Enhance Sorption Ability. Journal of Applied Polymer Science. 2004, Vol. 92, Is. 3, P. 1510-1515.

13. Özdemir G., Yapar S. Adsorption and desorption behavior of copper ions on Na-montmorillonite: Effect of rhamnolipids and pH. Journal of Hazardous Materials. 2009, Vol. 166, Is. 2-3, P. 1307-1313.

14. Xu H., Yang L., Wang P., Liu Y. Kinetic research on the sorption of aqueous lead by synthetic carbonate hydroxyapatite. Journal of Environmental Management. 2008, Vol. 86, Is. 1, P. 319-328.

15. Nadeem M., Shabbir M., Abdullah M.A. Sorption of cadmium from aqueous solution by surfactant-modified carbon adsorbents. Chemical Engineering Journal. 2009, Vol. 148, Is. $2-3$, P. $365-370$.

16. Di Natale F., Erto A., Lancia A., Musmarra D. Experimental and modelling analysis of $\mathrm{As}(\mathrm{V})$ ions adsorption on granular activated carbon. Water Research. 2008, Vol. 42, Is. 8-9. P. 2007-2016.

17. Azizian S., Haerifar M., Bashiri H. Adsorption of methyl violet onto granular activated carbon: Equilibrium, kinetics and modeling. Chemical Engineering Journal. 2009, Vol. 146, Is. 1, P. 36-41.

18. Rao G., Lu C., Su F. Sorption of divalent metal ions from aqueous solution by carbon nanotubes: A Review. Separation and Purification Technology. 2007, Vol. 58, Is. 1, P. 224-231.

19. Zhang L., Huang T., Zhang M., Guo X. Studies on the capability and behavior of adsorption of thallium on nano- $\mathrm{Al}_{2} \mathrm{O}_{3}$. Journal of Hazardous Materials. 2008, Vol. 157, Is. 2-3, P. 352-357.

20. Debnath S., Ghosh U. Nanostructured hydrous titanium(IV) oxide: Synthesis, characterization and Ni (II) adsorption behavior. Chemical Engineering Journal. 2009, Vol. 152, Is. $2-3$, P. $480-491$.

\section{DeAr COlleagues!}

THE REFERENCE TO THIS PAPER HAS THE FOLLOWING CITATION FORMAT:

Malkin P. Wastewater treatment system based on nanomodified natural sorbents. Nanotehnologii v stroitel'stve $=$ Nanotechnologies in Construction. 2018, Vol. 10, no. 5, pp. 56-72. DOI: dx.doi.org/10.15828/2075-8545-2018-10-5-56-72. 


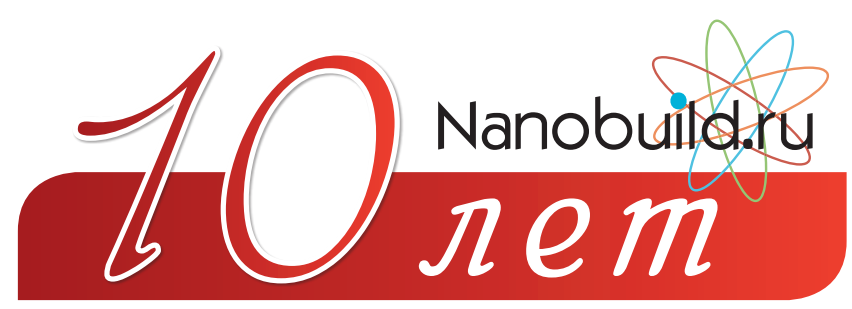

конкурс статей

УДК 628.316.12, 622.793.2, 622.793.5, 69.001.5

Автор: МАЛКИН Полад, д.ф.-м.н., старший научный сотрудник, Университет Бен-Гуриона

в Негеве, г. Беэр-Шева, Израиль; п/я 653, г. Беэр Шева, Израиль, 8410501,

polad.malkin@gmail.com

\section{СИСТЕМА ОЧИСТКИ СТОЧНЫХ ВОД С ИСПОЛЬЗОВАНИЕМ НАНОМОДИФИЦИРОВАННЫХ ПРИРОДНЫХ СОРБЕНТОВ}

\section{АННОТАЦИЯ К СТАТЬЕ (АВТОРСКОЕ РЕЗЮМЕ, РЕФЕРАT):}

Одной из глобальных проблем современности является защита водных ресурсов от загрязнения. Сточные воды практически всех хозяйствующих субъектов содержат нефтепродукты, соединения тяжелых металлов и другие виды загрязнений. Сегодня существует достаточно много эффективных систем очистки сточных вод с высокой степенью очистки до 99,9\%, но эксплуатация таких систем обусловлена значительными затратами, поэтому многие хозяйствующие субъекты пренебрегают экологическими нормами, несмотря на большие штрафные санкции.

Основной проблемой современных технологических систем применения является разработка экологически безопасных технологий с максимально замкнутым циклом и минимальным количеством отходов. Сложившаяся в настоящее время ситуация в этой области исследований вызвала необходимость совершенствования сорбционных технологий и селективных процессов очистки загрязненных растворов и технологических жидкостей для комплексного решения ресурсосберегающих и экологических проблем. В результате направленных исследований широкого спектра сорбционных материалов применительно к очистке сточных вод получили дальнейшее развитие процессы адсорбции нефтепродуктов и ионов тяжелых металлов на природных сорбентах и их аналогах.

Таким образом, создание экономически эффективных систем очистки сточных вод при сохранении высокой степени очистки является одной из самых актуальных проблем современности во всех странах. 
В работе предлагается многоступенчатая система очистки с использованием наноактивированных природных сорбентов, применяемая в замкнутом водооборотном цикле. Показано преимущество использования такой системы очистки по сравнению с существующими на примере хозяйствующих субъектов в машиностроительной отрасли России, США и Израиля.

Ключевые слова: природные сорбенты, сточные воды, экология, очистка воды, метод очистки воды, наноактивация, замкнутый водооборотный цикл, активация, цеолит, диатомит, модификация, нанотехнологии.

DOI: dx.doi.org/10.15828/2075-8545-2018-10-5-56-72

\section{МАШИНОЧИТАЕМАЯ ИНФОРМАЦИЯ О СС-ЛИЦЕНЗИИ В МЕТАДАННЫХ СТАТЬИ (НTML-КОД):}

$<$ a rel="license" href="http://creativecommons.org/licenses/by/4.0/" ><img alt="Creative Commons License" style="borderwidth:0" src="https://i.creativecommons.org/l/by/4.0/88x31.png" / $></ \mathrm{a}><$ br $/><$ span xmlns:dct="http://purl.org/dc/ terms/" href="http://purl.org/dc/dcmitype/Text" property="dct:title" rel="dct:type">Система очистки сточных вод с использованием наномодифицированных природных сорбентов $</$ span $>$ by $<$ a xmlns:cc="http://creativecommons.org/ns\#" href="Нанотехнологии в строительстве. - 2018. - Том 10, № 5. - С. 56-72. - DOI: dx.doi.org/10.15828/2075-8545-201810-5-56-72." property="cc:attributionName" rel="cc:attributionURL" $>$ Малкин $\Pi$. $</$ a $>$ is licensed under a $<$ a rel="license" href="http://creativecommons.org/licenses/by/4.0/" $>$ Creative Commons Attribution 4.0 International License $</ a>$. $<$ br />Based on a work at <a xmlns:dct="http://purl.org/dc/terms/" href="http://nanobuild.ru/ru_RU/nanobuild-5-2018/" rel="dct:source" $>$ http://nanobuild.ru/ru RU/nanobuild-5-2018/</a $>.<$ br $/>$ Permissions beyond the scope of this license may be available at $<$ a xmlns:cc="http://creativecommons.org/ns\#" href="polad.malkin@gmail.com" rel="cc:morePermissions" $>$ polad. malkin@gmail.com $</ a>$.

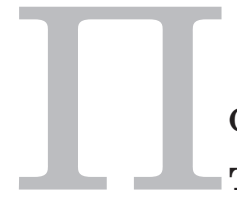

остроение системы очистки воды на хозяйствующих субъектах решается не всегда одинаково, так как технология очистки воды зависит не только от требований к качеству очищенной воды, но и от технологической и экономической возможности ее проведения. В очистке сточных вод успешно функционируют такие методы, как очистка воды активным илом, центрифугирование, сорбция, флотация, обработка воды ультрафиолетом или озонирование, микро- и нанофильтрация. Самые популярные и эфрективные из известных методов водоподготовки и очистки сточных вод: физико-химические методы очистки, биологические методы, как аэробные, так и анаэробные методы, очистка сточных вод с использованием мембран, термические методы 
очистки, очистка сточных вод с использованием озона, абсорбционные методы очистки с использованием активированного угля, ионообменные методы для селективного извлечения загрязняющих веществ. Каждый из перечисленных методов обладает своими достоинствами и недостатками. Выбор того или иного способа зависит от ряда факторов, таких как масштаб загрязнения, его специфика и экономическая целесообразность. Существующие экологические нормы требуют от хозяйствующих субъектов реализовать новые или же модернизировать имеющиеся очистные сооружения [1-8].

В России наиболее популярны химические и физико-химические методы очистки промышленных сточных вод. Химическая очистка осуществляется с помощью разнообразных химических реагентов, вступающих в реакцию с загрязняющими веществами. В результате их воздействия образуются нерастворимые осадки. Физико-химическая очистка воды объединяет в себя несколько методов:

- коагуляцию - добавление в стоки коагулятов при реакции, с которыми получаются осадки в виде хлопьев, которые потом можно просто удалить;

- $\quad$ флотацию - пропускание через стоки воздушных пузырьков. Они при движении вверх прихватывают с собой масла, поверхностноактивные вещества и прочие загрязнения. На поверхности сточных вод в результате образуется пена;

- сорбцию - использование материалов, которые могут впитывать загрязняющие вещества. Предварительно обязательно проводят механическую очистку.

Израиль в 2010 году и в последующих годах был признан лучшим по очистке промышленных сточных вод. На сегодня Израиль также остается одним из мировых лидеров в данной сфере. Основными способами считаются: химический, механический, физико-химический, биологический. Кроме традиционных методов очистки воды и стоков в Израиле разработаны новые, более экологичные и экономически выгодные способы: мембранные, электрохимические, магнитная обработка, озонирование, обработка селективными сорбентами. Каждый из этих способов позволяет эффективно удалять различные загрязнения, при минимальных вредных побочных воздействиях на окружающую среду.

В США самый популярный промышленный метод очистки стоков метод мембранной очистки. Интерес к технологии ультрафильтрации 
среди специалистов США подогревается растущими масштабами ее применения. Метод мембранной фильтрации основан на том, чтобы при пропуске через себя отдавать предпочтение каким-либо веществам, при этом задерживая инородные для мембраны примеси. Основное преимущество указанного метода - практически полная очистка жидкости от инородных примесей и соединений. Тщательная фильтрация не дает возможности возврата в воду загрязняющих веществ.

Анализ данных по очистке промышленных сточных вод был проведен на хозяйствующих субъектах таких стран, как Россия, США и Израиль. Выборка данных проводилась по пяти хозяйствующим субъектам машиностроительной отрасли от каждой страны, результаты представлены в табл. 1., где $\mathrm{C}_{\text {исх }}$ - исходная концентрация примеси, $\mathrm{C}_{\text {вых }}$ - выходная концентрация примеси, $\alpha$ - степень извлечения.

Таблица 1

Концентрация тяжелых металлов в сточных водах до и после очистки на хозяйствующих субъектах машиностроительной отрасли по странам

\begin{tabular}{|c|c|c|c|c|c|c|c|c|c|}
\hline \multirow{3}{*}{$\begin{array}{l}\text { Извлекае- } \\
\text { мое веще- } \\
\text { ство }\end{array}$} & \multicolumn{3}{|c|}{ Россия } & \multicolumn{3}{|c|}{ CIIA } & \multicolumn{3}{|c|}{ Израиль } \\
\hline & $\begin{array}{l}\mathrm{C}_{\text {иес }}, \\
\mathbf{M \Gamma} / \text { J }\end{array}$ & $\begin{array}{l}\mathrm{C}_{\text {вБIx }}, \\
\mathbf{M \Gamma / J}\end{array}$ & $\alpha,(\%)$ & $\begin{array}{l}\mathrm{C}_{\text {ucx }}, \\
\mathbf{M \Gamma} / \mathbf{I}\end{array}$ & $\begin{array}{l}\mathrm{C}_{\text {вых }}, \\
\mathbf{M \Gamma} / \text { J }\end{array}$ & $\alpha,(\%)$ & $\begin{array}{l}\mathbf{C}_{\text {ncx }}, \\
\mathbf{M \Gamma} / \text { J }\end{array}$ & $\begin{array}{l}\mathrm{C}_{\mathrm{Bbx}}, \\
\mathbf{M \Gamma} / \boldsymbol{J}\end{array}$ & $\alpha,(\%)$ \\
\hline & \multicolumn{9}{|c|}{$\mathrm{pH}=3-11$} \\
\hline $\mathrm{Fe}$ & 150,4 & 0,3 & 99,8 & 75,9 & 0,1 & 99,9 & 75,0 & 0,1 & 99,9 \\
\hline $\mathrm{Cu}$ & 10,3 & 0,4 & 96,1 & 9,7 & 0,35 & 96,4 & 13,6 & 0,3 & 97,8 \\
\hline $\mathrm{Zn}$ & 22,8 & 0,8 & 96,5 & 20,6 & 0,5 & 97,6 & 21,4 & 0,6 & 97,2 \\
\hline $\mathrm{Cr}_{\text {общ }}$ & 95,3 & 0,3 & 99,7 & 89,5 & 0,2 & 99,8 & 90,7 & 0,2 & 99,8 \\
\hline $\mathrm{Ni}$ & 1,06 & 0,07 & 93,4 & 1,09 & 0,06 & 94,5 & 1,15 & 0,07 & 93,9 \\
\hline $\mathrm{Pb}$ & 2,6 & 0,1 & 96,1 & 2,9 & 0,08 & 97,2 & 2,2 & 0,04 & 98,2 \\
\hline $\mathrm{Cr}^{6+}$ & 3,5 & 0,1 & 97,1 & 2,5 & 0,05 & 98,0 & 2,5 & 0,05 & 98,0 \\
\hline Прочие & 6 & 0,2 & 96,6 & 4,5 & 0,02 & 99,6 & 4,7 & 0,01 & 99,8 \\
\hline
\end{tabular}


Данные табл. 1 сформированы по среднему значению концентраций на выбранных хозяйствующих субъектах в наиболее загрязненной тяжелыми металлами отрасли. Приведенные результаты свидетельствуют, что методы, используемые для очистки в России, уступают уровню очистки стоков хозяйствующих субъектов в США и Израиле. Все используемые методы являются достаточно дорогостоящими, в особенности в США и Израиле. Поиск и разработка новых экономически целесообразных и высокоэффективных методов очистки воды является приоритетом для данных стран.

Применение наноматериалов, обладающих уникальными физико-химическими и поверхностными свойствами, открывает новые возможности в очистке сточных вод. Реализация нанотехнологий в производстве очистки воды является одним из перспективных направлений улучшения качества очистки. Так, в работе [9] предлагается для очистки сточных вод, содержащих широкий спектр загрязняющих веществ, применять сорбционную очистку с помощью наномодифицированных природных сорбентов - наноактивированного комплекса из цеолита и диатомита. Для природных цеолита и диатомита присущи повышенная ионообменная емкость, способность обмениваться катионами, невысокая цена и распространенность.

Основным компонентом выбранных природных сорбентов является оксид кремния. Его содержание в диатомите доходит до $80 \%$, в цеолите оксида кремния около 70\% . В данных минералах содержатся также оксиды алюминия, железа, титана, кальция, магния, натрия, калия, другие оксиды.

По предложенной методике [9] были проведены испытания на адсорбционную способность сорбента к наибольшим концентрациям тяжелых металлов в сравнении с концентрациями на выбранных хозяйствующих субъектах, приведенных в табл. 1. Результаты испытаний приведены в табл. 2.

Степень извлечения вычисляли по уравнению:

$$
\alpha=\left(\mathrm{C}_{\text {исх }}-\mathrm{C}_{\text {вых }}\right) \cdot 100 / \mathrm{C}_{\text {исх }} \text {, }
$$

где $\mathrm{C}_{\text {исх }}$ - исходная концентрация примеси, $\mathrm{C}_{\text {вых }}$ - выходная концентрация примеси. 
Таблица 2

Результаты сорбции тяжелых металлов, наноактивированных комплексом природных сорбентов

\begin{tabular}{|l|c|c|c|}
\hline \multirow{2}{*}{$\begin{array}{c}\text { Извлекаемое } \\
\text { вещество }\end{array}$} & \multicolumn{2}{|c|}{$\mathbf{p H}=\mathbf{3 - 1 1}$} & \multirow{2}{*}{$\alpha,(\%)$} \\
\cline { 2 - 3 } & $\mathbf{C}_{\text {исх }}, \mathbf{M г} / \mathbf{J}$ & $\mathbf{C}_{\text {вых }}, \mathbf{M г} / \mathbf{л}$ & 99,9 \\
\hline $\mathrm{Fe}$ & 200 & 0,1 & 99 \\
\hline $\mathrm{Cu}$ & 15 & 0,15 & 99,4 \\
\hline $\mathrm{Zn}$ & 27 & 0,15 & 99,9 \\
\hline $\mathrm{Cr}_{\text {общ }}$ & 105 & 0,1 & 99,8 \\
\hline $\mathrm{Ni}$ & 5 & 0,01 & 99,8 \\
\hline $\mathrm{Pb}$ & 5 & 0,01 & 99,8 \\
\hline $\mathrm{Cr}^{6+}$ & 5 & 0,01 & 99,9 \\
\hline Прочие & 10 & 0,01 & \\
\hline
\end{tabular}

Как свидетельствуют данные табл. 2, результаты испытания наномодифицированного сорбента на адсорбционную способность по отношению к извлекаемым веществам показали, что этот сорбент может быть успешно применен для очистки сточных вод от ионов тяжелых металлов. Таким образом, методика [9] очистки промышленных сточных вод от тяжелых металлов является наиболее эффективной.

Предлагается внедрение водооборотных циклов, построенных на основе систем многоступенчатой очистки, предложенной в работе [10] с использованием наноактивированных комплексов природных сорбентов, а также повторное использование очищенных вод в оборотных системах охлаждающей воды и др. Данная система является наиболее экономически эффективным способом очистки сточных вод для хозяйствующих субъектов, принципиальная схема которых указана на рис. 1 .

В отличие от прямоточной системы водоснабжения, которая обычно применяется при малом водопотреблении и близком расположении источника воды, полная оборотная система водоснабжения предусматривает возврат использованной воды в производственный цикл. Технологии, позволяющие возвращать очищенные сточные воды или регенерировать технологические растворы, имеют огромное значение. 


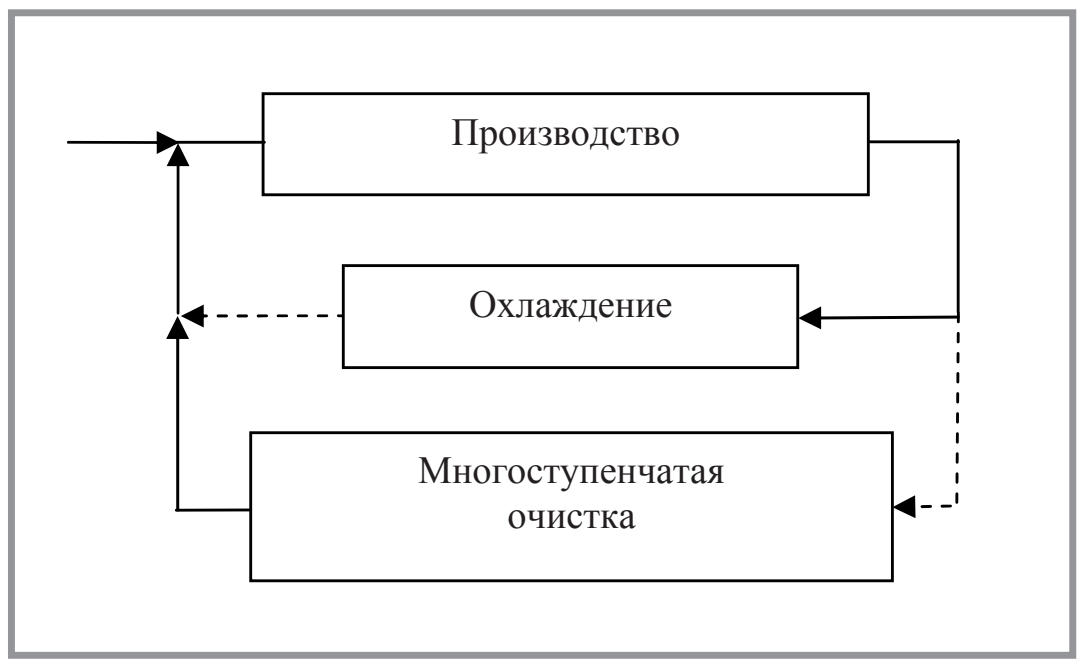

Рuc. 1. Схема замкнутого водообменного цикла

Большая часть современных хозяйствующих субъектов является активными потребителями водных ресурсов. Для экономической и экологической целесообразности лучше отдать предпочтение прогрессивному способу оборотного водоснабжения, подразумевающему многократное использование этого ресурса. Повторное использование отработанных сточных вод после их очистки на тех же технологических операциях или для других производственных нужд является одним из эффективных путей уменьшения количества промышленных стоков, сбрасываемых в водоемы, а также снижения затрат на хозяйствующих субъектах.

Главными преимуществами многоступенчатых систем в замкнутом водооборотном цикле для очистки промышленных стоков с использованием наномодифицированных природных сорбентов являются: возможность одновременного удаления различных соединений тяжелых металлов в одну стадию, соединения тяжелых металлов клатратируются в виде кристаллических невыщелачиваемых продуктов, наряду с растворенными тяжелыми металлами эффективно удаляются диспергированные взвеси и эмульгированные загрязнения, процесс не чувствителен к влиянию других солей, которые могут присутствовать в стоках в больших концентрациях [11-20].

Результаты испытания новой системы очистки доказали большую эффективность в сравнении с используемыми в хозяйствующих субъектах России, США и Израиля. Степень извлечения ПО составляет 99,9\% в сочетании с высокой экономической эффективностью. Кроме того, при 
использовании предложенного сорбента не происходит высвобождение тяжелых металлов, а процесс поглощения тяжелых металлов активно продолжается.

Анализ современного состояния очистки сточных вод от тяжелых металлов на выбранных хозяйствующих субъектах приводит к заключению о перспективности применения разработанной системы очистки на основе наномодифицированных природных сорбентов, а также позволяет рекомендовать их для практического использования для очистки сточных вод на хозяйствующих субъектах России, США и Израиля.

\section{Библиографический список:}

1. Javadian H., Ghorbani F., Tayebi H., Asl S.H. Study of the adsorption of Cd (II) from aqueous solution using zeolite-based geopolymer, synthesized from coal fly ash; kinetic, isotherm and thermodynamic studies. Arabian Journal of Chemistry. 2015, Vol. 8, Is. 6, P. 837-849.

2. Blanchard G., Maunaye M., Martin G. Removal of Heavy from Waters by Means of Natural Zeolites. Water Research. 1984, Vol. 18, Is. 12, P. 1501-1507.

3. Benkli Y.E., Can M.F., Turan M., Celik M.S. Modification of organo-zeolite surface for the removal of reactive azo dyes in fixed-bed reactors. Water Research. 2005, Vol. 39, Is. 2-3, P. 487-493.

4. Baker H.M., Massadeh A.M., Younes H.A. Natural Jordanian zeolite: Removal of heavy metal ions from water samples using column and batch methods. Environmental Monitoring and Assessment. 2009, Vol. 157, Is. 1-4, P. 319-330.

5. Gao Z., Bandosz T., Zhao Z., Han M. Investigation of factors affecting adsorption of transition metals on oxidized carbon nanotubes. Journal of Hazardous Materials. 2009, Vol. 167, Is. 1-3, P. 357-365.

6. Wan Ngah W.S., Hanafiah M.A. Removal of heavy metal ions from wastewater by chemically modified plant wastes as adsorbents: A Review. Bioresource Technology. 2008, Vol. 99, Is. 10, P. 3935-3948.

7. Cincotti A., Mameli A., Locci A.M., Orru R., Cao G. Heavy metals uptake by Sardinian natural zeolites: Experiment and modeling. Industrial \& Engineering Chemistry Research. 2006, Vol. 45, Is. 3, P. 1074-1084.

8. Margeta K., Logar N.Z., Šiljeg M., FarkašA. Natural zeolites in water treatment - How effective is their use. INTECH, Open publication, 2013. http://dx.doi.org/10.5772/50738.

9. Малкин П. Очистка сточных вод от ионов тяжелых металлов с помощью наноактивированных комплексов природного цеолита и диатомита// Нанотехнологии в строительстве. - 2018 - Том. 10, № 2 - С. 21-41.

10. Malkin P. Method, system and device for cleaning and regeneration water. US Patent App. 62/592,411; 2017. 
11. Malkin P. Method of Wastewater Treatment from Heavy Metal Ions Using Nanoactivated Complexes of Natural Zeolite and Diatomite. Young Scientist USA, Vol. 10, 2017, pp. 17-21.

12. Lukaszczyk J., Lekawska E., Lunkwitz K., Petzold G. Sorbents for Removal Surfactants from Aqueous Solutions. Surface Modification of Natural Solids to Enhance Sorption Ability. Journal of Applied Polymer Science. 2004, Vol. 92, Is. 3, P. 1510-1515.

13. Özdemir G., Yapar S. Adsorption and desorption behavior of copper ions on Na-montmorillonite: Effect of rhamnolipids and pH. Journal of Hazardous Materials. 2009, Vol. 166, Is. 2-3, P. 1307-1313.

14. Xu H., Yang L., Wang P., Liu Y. Kinetic research on the sorption of aqueous lead by synthetic carbonate hydroxyapatite. Journal of Environmental Management. 2008, Vol. 86, Is. 1, P. 319-328.

15. Nadeem M., Shabbir M., Abdullah M.A. Sorption of cadmium from aqueous solution by surfactant-modified carbon adsorbents. Chemical Engineering Journal. 2009, Vol. 148, Is. $2-3$, P. $365-370$.

16. Di Natale F., Erto A., Lancia A., Musmarra D. Experimental and modelling analysis of As(V) ions adsorption on granular activated carbon. Water Research. 2008, Vol. 42, Is. 8-9. P. 2007-2016.

17. Azizian S., Haerifar M., Bashiri H. Adsorption of methyl violet onto granular activated carbon: Equilibrium, kinetics and modeling. Chemical Engineering Journal. 2009, Vol. 146, Is. 1, P. 36-41.

18. Rao G., Lu C., Su F. Sorption of divalent metal ions from aqueous solution by carbon nanotubes: A Review. Separation and Purification Technology. 2007, Vol. 58, Is. 1, P. 224-231.

19. Zhang L., Huang T., Zhang M., Guo X. Studies on the capability and behavior of adsorption of thallium on nano- $\mathrm{Al}_{2} \mathrm{O}_{3}$. Journal of Hazardous Materials. 2008, Vol. 157, Is. 2-3, P. 352-357.

20. Debnath S., Ghosh U. Nanostructured hydrous titanium(IV) oxide: Synthesis, characterization and Ni (II) adsorption behavior. Chemical Engineering Journal. 2009, Vol. 152, Is. $2-3$, P. $480-491$.

\section{УВАЖАЕМЫЕ КОЛЛЕГИ!}

ПРИ ИСПОЛЬЗОВАНИИ МАТЕРИАЛА ДАННОЙ СТАТЬИ

ПРОСИМ ДЕЛАТЬ БИБЛИОГРАФИЧЕСКУЮ ССЫЛКУ НА НЕЁ:

Малкин П. Система очистки сточных вод с использованием наномодифицированных природных сорбентов // Нанотехнологии в строительстве. - 2018. - Том 10, № 5. - C. 56-72. - DOI: dx.doi.org/10.15828/2075-8545-2018-10-5-56-72.

\section{DeAR COlleagues!}

THE REFERENCE TO THIS PAPER HAS THE FOLLOWING CITATION FORMAT:

Malkin P. Wastewater treatment system based on nanomodified natural sorbents. Nanotehnologii v stroitel'stve $=$ Nanotechnologies in Construction. 2018, Vol. 10, no. 5, pp. 56-72. DOI: dx.doi.org/10.15828/2075-8545-2018-10-5-56-72. 